\title{
Pengembangan Media Pembelajaran Interaktif Berbasis Articulate Storyline Tematik Terhadap Minat Belajar Siswa Kelas 4 SD
}

\section{Rika Kurnia Sari ${ }^{1 *}$, Nyoto Harjono ${ }^{1}$}

${ }^{1}$ Program Studi Pendidikan Guru Sekolah Dasar, Universitas Kristen Satya Wacana,

Salatiga, Indonesia,

*e-mail: 292017045@student.uksw.edu

\begin{abstract}
Abstrak
Kurangnya minat belajar siswa disebabkan oleh terbatasnya media pembelajaran yang digunakan guru dalam melakukan proses pembelajaran serta kurangnya kompetensi yang dimiliki guru sehingga tidak dapat memanfaatkan teknologi sebagai media pembelajaran. Tujuan penelitian ini adalah menghasilkan media pembelajaran interaktif berbasis Artiqulate Storyline tematik pada mapel tematik untuk meningkatkan minat belajar siswa kelas IV Sekolah Dasar. Metode penelitian yang digunakan yaitu $R$ \& $D$ dengan model pengembangan ADDIE yang terdiri atas 5 tahap, yaitu analysis, design, development, implemation dan evaluatioan. Subjek penelitian ini adalah 15 siswa yang akan melakukan uji coba media, ahli media, dan ahli meteri. Teknik pengumpulan data dilakukan dengan observasi, wawancara dan angket. Analisis data yang digunakan adalah analisis deskriptif dan kategoris untuk melihat kelayakan media yang dikembangkan. Hasil penelitian diperoleh media interaktif berbasis Artiqulate Storyline dapat dikatakan layak dengan hasil pengujian ahli materi sebesar $81 \%$ yang dikategorikan sangat baik dan dari ahli media sebesar $78 \%$ yang dapat dikategorikan baik. Sedangkan dari hasil respon lembar angket siswa memiliki hasil validitas rata-rata $r$ hitung tingkat validasi angket minat belajar siswa sebesar 0,598 , maka pernyataan tersebut dinyatakan valid. Dan untuk hasil realibilitasnya sebanyak 0,925 termasuk ke dalam kategori sangat baik dengan Dari pengujian yang sudah dilakukan media interaktif berbasis Artiqulate Storyline ini layak digunakan untuk membantu guru dalam menyampaikan materi pembelajaran dan membantu siswa untuk menumbuhkan minat dalam mengikuti kegiatan pembelajaran.
\end{abstract}

Kata kunci: pengembangan, media interaktif, minat belajar

\begin{abstract}
Lack of student interest in learning is caused by the limited learning media used by the teacher in carrying out the learning process and the competence of the teacher so that they cannot use technology as a learning medium. The purpose of this study was to develop interactive learning media based on thematic Artiqulate Storylines on thematic subjects to increase the learning interest of grade IV elementary school students. The research method used is $R \& D$ with the ADDIE development model which consists of 5 stages, namely analysis, design, development, implementation and evaluation. Feasibility of products developed by experts who are competent in their fields through validation instrument sheets of media and material experts. After expert validation, the instrument validity and reliability were tested after going through limited trials in different primary schools. Interactive media based on the Artiqulate Storyline can be said to be feasible with the results of testing the material by $81 \%$ which is categorized as very good and from media experts as much as $78 \%$ which can be categorized well. Whereas from the results of the responses to the questionnaire, the students had the results of the average validity of $r$ count the validation level of the questionnaire for student learning interest of 0.598 , the statement was declared valid. And for reliability results as much as 0.925 is included in the very good category. From the tests that have been carried out, interactive media based on the Artiqulate Storyline is suitable to be used to assist teachers in delivering learning material and helping students to grow interest in participating in learning activities.
\end{abstract}

Keywords: development, interactive media, interest in learning 


\section{Pendahuluan}

Pembelajaran adalah adalah tejadinya proses interaksi antara siswa dengan sumber belajar untuk terhuwujudnya tujuan pembelajaran. Pembelajaran yang baik adalah pembelajaran yang dapat meningkatkan kemampuan berpikir HOTS dan kreativitas siswa (Gurung, 2020; Henriksen et al., 2020; Idris \& Sida, 2019; Idris et al., 2019), serta pembelajaran yang baik adalah pembelajaran yang memberikan kesempatan kepada siswa untuk aktif dalam membangun pengetahuannya sendiri. Dengan aktif membangun pengetahunnya sendiri dan mengembangkan kecerdasan emosi siswa akan lebih banyak mendapatkan pengalaman yang membuat pembelajaran lebih bermakna (Angela, 2014; Kostiainen et al., 2018). Membuat pembelajaran lebih bermakna tidak terlepas dari komponen-komponen pembelajaran yang harus dirancang oleh guru. Salah satu komponen pembelajaran yang tidak dipisahkan dari proses pembelajaran adalah media pembelajaran (Safriandono \& Charis, 2014). Media pembelajaran adalah salah satu alat komunikasi yang digunakan oleh guru untuk menyampaikan materi kepada siswa. Media pembelajaran akan membuat pembelajaran lebih efektif dan efisien (Nurrita, 2018; Silalahi, 2020), medai pembelajaran membuat pembelajaran menarik sehingga membuat siswa aktif dan tertarik dalam mengikuti pembelajaran (Karo \& Rohani, 2018; Tafonao, 2018; Wahid et al., 2020) selian itu adalanya media pembelajaran juga dapat meningkatkan minat siswa dalam menikuti pembelajaran (Marwatoen, 2015). Tumbuhnya minat siswa dalam proses pembelajaran akan berpengaruh terhadap hasil bejar siswa. semakin tinggi minat siswa dalam proses pembelajaran maka hasil belajar siswa akan menunjukkan peningkatan. Oleh sebab itu pembuatan dan penggunaan media dalam proses pembelajaran harus disesuaikan dengan karateritik siswa dan perkembangan teknologi saat ini.

Namun, kenyataannya rata-rata guru sekolah dasar belum memanfaatkan teknologi sebagai media pembelajaran dengan baik, guru masih banyak yang menggunakan metode konvensional dalam penyampaian materi (Agustini et al., 2016). Tidak semua guru mampu menggunakan media berbasis teknologi (Shalikhah et al., 2018), selain itu jumlah media pembelajaran di SD masih kurang (Andriani, 2016). Media pembelajaran yang masih digunakan bersifat konvensional, masih sedikit guru yang memanfaatkan teknologi dalam pembuatan media. Saat ini, proses pembelajaran baik daring maupun luring guru belum memanfaatkan teknologi dengan maksimal, saat pembelajaran daring guru menggukan via Whatshapp dan video pembelajaran dari yautube sedangkan saat pembelajaran luring guru hanya menggunakan buku. Penggunan media seperti itu membuat guru terbatas dalam menyampaikan materi terutama pada mapel tematik sehingga guru merasa proses pembelajaran tidak berjalan dengan baik karena siswa tidak memperhatikan guru saat menjelaskan, yang berdampak terhadap banyak siswa yang belum paham mengenai materi yang disampaikan. Jika hal ini diabirakan akan berdampak terhadap minat belajar siswa yang akan mempengaruhi hasil belajar siswa.

Salah satu solusi yang dibisa dilakukan adalah dengan mengembangkan media pebelajaran interaktif. Media pembelajaran interaktif berkontribusi positif dalam meningkatkan pemahaman siswa (Saputro et al., 2016), membatu siswa untuk memahami konsep matematika (Jundu et al., 2019), dapat memotivasi siswa untuk belajar mandiri, kreatif, efektif, dan efisien (Rezeki \& Ishafit, 2017). Beberapa penelitian yang dilakukan tentang media interaktif sebelumnya memberikan dampak yang positif terhadap pembelajaran. Penelitian yang dilakukan oleh Usfiyana, (2019) menghasilkan media pembelajaran interaktif berbasis Adobe Flash CS6 dianggap layak dijadikan sebagai media pembelajaran. Sofnidar \& Yuliana, (2018) menghasilkan media interaktif dengan aplikasi adobe flash dan fhotoshop berbasis pendekatan saintifik layak, efisien dan efektif digunakan sebagai media pembelajaran. Kumalasari, (2018) mengemukakan bahwa multimedia interaktif sebagai salah satu alternatif media pembelajaran untuk menjadikan pembelajaran lebih berkualitas. Widjayanti et al., (2018) menghasilkan bahwa media pembelajaran interaktif berbasis animasi layak digunakan dalam pembelajaran matematika pada materi statistika. Arda et al., (2015) menghasilkan bahwa media 
interaktif berbasis computer layak digunakan dalam prose pembelajaran khususnya mengembangkan pemahan konsep. Rafmana \& Chotimah, (2018) menghasilkan multimedia interaktif berbasis articulate storyline dinyatakan valid, praktis dan mempunyai efek potensial untuk meningkatkan motivasi belajar siswa di SMA. Yumini \& Rakhmawati, (2015) menghasikan media pembelajaran interaktif berbasis articulate storyline sangat layak digunakan sebagai media di SMK. Setyaningsih et al., (2020) menyatakan bahwa penggunaan media pembelajaran interaktif berbasis articulate storyline terhadap motivasi belajar dan hasil belajar IPS siswa kelas IV SD. Jadi, dapat dikatakan bahwa mediamedia interaktif dengan jenis aplikasi yang dikembangkan layak digunakan dan berdampak positif.

Jabaran tersebut menjadi salah satu alasan penelitian yang bertujuan menghasilkan media pembelajaran interaktif berbasis Artiqulate Storyline tematik pada mapel tematik untuk meningkatkan minat belajar siswa kelas IV Sekolah Dasar dilaksanakan. Media berbasis Articulate storyline yang memiliki tampilan seperti powerpoint, namun articulate memilki keunggulan lebih dibandingkan dengan power point, keunggulan yang dimiliki Articulate storyline yaitu memiliki fitur penambahan character,berbagai macam kuis, link url dan tombol, terdapat pula layer yang dapat memisahkan objek yang satu dengan lainnya, terdapat pula trigger yang berfungsi mengarahkan tombol ketempat yang kita inginkan, selain itu juga memiliki berbagai format publish seperti LMS, html5, Articulate storyline online, CD , dan word sehingga hasil produknya terlihat lebih komprehensif, interaktif dan efektif. Software ini memiliki layar kerja berupa scene dan slide serta memiliki fitur seperti audio, video, gambar, character dan link Url dari website sehingga dapat menyajikan sumber materi menjadi menarik dan lengkap. Lengkapnya komponen pada artiqulate storyline dapat membuat masing-masing siswa belajar melalui gaya belajar berupa audiotori dan Visual sehingga dapat memaksimalkan penerimaan materi pada siswa. Articulate storyline ini dapat diakses secara online maupun ofline karena dapat di publish berbentuk web, articulate online, LMS, CD dan word sehingga produk yang dihasilkan dapat digunakan pada PC, leptop maupun smartphone maka dari itu dapat memudahkan siswa belajar dimana saja dan kapansaja selain itu dapat menarik minat siswa. Media pembelajaran interaktif berbasis artiqulate storyline yang didalamnya terdapat materi pembelajaran beserta game edukatif yang nantinya dikembangkan dalam bentuk aplikasi untuk android, CD interaktif dan html 5 atau WEB untuk leptop/ pc. Media ini dikembangkan untuk kelas 4 dengan Tema 7 Subtema 1 Pembelajaran ke-3, pemilihan materi ini berdasarkan diskusi dengan guru wali kelas IV. Dengan pengembangan ini diharapkan dapat membantu guru dalam menyampaikan materi serta dapat memudahkan siswa dalam menerima materi pembelajaran, memberikan ketertarikan dan semangat belajar saat proses kegiatan pembelajaran yang dilakukan secara daring maupun luring.

\section{Metode}

Jenis penelitian pengembangan yang digunakan peneliti adalah $R \& D$, model pengembangan ADDIE yang dikembangkan oleh Dick and Carry. ADDIE memiliki 5 tahapan yaitu Analysis, Design, Development, Implementation, Evaluation menurut Dick and Carry (Tegeh et al., 2019). Tahap Analisis, analisis merupakan Tahap awal yang dilakukan peneliti untuk mencari permasalahan. Langkah yang dilakukan yaitu langkah analisis pembelajaran, analisis siswa dan guru. Pada tahap ini dilakukan wawancara dengan guru kelas 4 untuk mengetahui permasalahan yang dihadapi saat kegiatan belajar mengajar berlangsung. Tahap Perancangan, pada tahap kedua mulai menentukan solusi yang tepat berupa produk yang dituangkan dalam bentuk perencanaan desain. pada tahap ini akan gambarkan garis besar isi media pembelajaran interaktif menggunakan Articulate Storyline yang dituangkan dalam bentuk flow chart dan naskah untuk mempermudah proses pengembangan pada tahap berikutnya. Di dalam design tersebut terdapat kompetensi, materi, geme, kuis dan profil pengembangan.

Tahap Pengembangan, Development merupakan tahap merealisasikan rancangan produk yang sudah di buat berdasarkan desain pengembangan media 
pembelajaran interaktif dari artiqulate storyline. Sebelum diterapkan dalam pembelajaran terlebih dahulu dilakukan pengecekan dan validasi kepada ahli materi dan ahli media. Validasi dilakukan untuk mengetahui isi dan media yang dikembangkan dilakukan oleh validator. Tahap Penerapan, tahap implementasi merupakan penerapangan rancangan produk yang telah dikembangkan pada situasi yang nyata untuk uji coba pengembangan secara terbatas pada sekolah yang dipilih sebagai tempat penelitian. Pada tahap ini guru melakukan kegiatan pembelajaran dengan bantuan media yang sudah dikembangkan setelah itu peneliti melakukan evaluasi untuk memberi umpan balik pada penerapan media berikutnya. Penerapan media dilakukan secara uji terbatas dengan 15 siswa dikarenakan disaat corona tidak memungkinkan dilakukannya Uji luas. Tahap Evaluasi, evaluasi merupakan tahap terakhir dari pengembangan ini, dimana pada tahap ini peneliti melakukan evaluasi terakhir terhadap media interaktif yang sudah di uji sebelumnya dan kemudian diperbaiki sesuai dengan masukan yang di terima. Tujuan evaluasi ini untuk menganalisis validitas media, kelayakan media dan minat belajar siswa setelah menggunakan media yang dikembangkan pada tahap implementasi. Tahap evaluasi dilakukan berdasarkan angket yang sudah diisi oleh validator dan angket minat belajar siswa.

Subjek penelitian ini adalah 15 siswa pada 3 SD yang berbeda, yaitu 5 siswa di SDN Pringapus 03, 5 siswa di SDN Pringapus 02 dan 5 siswa SDN Sambirejo 02. Ahli media dan ahli materi. Hal ini untuk mengetahui seberapa valid dan layak digunkan media yang dikembangkan. Teknik pengumpulan data ini menggunakan wawancara dan angket. Wawancara dilakukan dengan guru SD 03 Pringapus sedangkan angket diberikan kepada uji pakar ahli materi dan uji pakar ahli media untuk menguji kelayakan suatu media pembelajaran interaktif yang dibuat. Lembar angket pada uji pakar menggunakan skala linkert dengan rentang skor 1-5 dengan kriteria tidak baik sampai sangat baik. Angket minat siswa sebelum digunakan dilakukan uji validitas dan realibilitas. Perhitungan validitas dapat dihitung dengan menggunakan rumus korelasi pearson product moment. Sedangkan untuk menguji reliabilitas dapat dihitung dengan menggunakan metode Cronbach's-Alpha. Analisis data yang diperoleh dilakukan dengan cara analisis deskriptif dan kategoris untuk melihat kelayakan media yang dikembangkan melalui angket yang diberikan kepada ahli media dan materi. Hasil penilaian angket dijumlahkan kemudian dirata-rata hasilnya. Dari hasil skor yang diperoleh dapat dikategorikan pada tabel 1 berikut.

Tabel 1. Indeks Validasi Ahli

\begin{tabular}{cc}
\hline Interval & Kategori \\
\hline $81-100 \%$ & Sangat Baik \\
$61-80 \%$ & Baik \\
$41-60 \%$ & Cukup \\
$21-40 \%$ & Rendah \\
$1-20 \%$ & Sangat Rendah \\
\hline
\end{tabular}

\section{Hasil dan Pembahasan Hasil Penelitian}

Tahap analisis yang dilakukan adalah dengan menganalisis permasalahan yang terjadi pada subjek penelitian dengan cara mewawancarai wali kelas 'IV di 3 sekolah yang berbeda. Dari hasil wawancara yang sudah dilakukan, guru tidak pernah menggunakan media interaktif sebagai media pembelajaran hal itu karna guru tidak memiliki waktu untuk belajar dan membuat media dan tidak memiliki keahlian untuk membuatnya sehingga dalam pembelajaran daring menggunakan video dan whatshapp sebagai media pembelajaran dan luring dengan menggunakan buku.

Tahap perancangan ini dengan melakukan penyusunan Media linteraktif Berbasis Articulate Storyline yang pertama dengan mencari materi pembelajaran. Materi 
pembelajaran tema 7 Indahnya Keragaman di Negeriku subtema 1 Kebragaman Suku Agama di negeriku pembelajaran ke-3. Menyiapkan buku-buku sumber dan referensi lainya seperti blog ataupun Wikipedia. Selanjutnya Merancang isi media interaktif berbasis articulate storyline yang didalamnya terdiri dari intro/ pembuka media petunjukdan menu utama. Pada petunjuk terdapat petunjuk tombol dan prosedur penggunaan media sedangkan pada menu utama terdapat kompetensi, materi, game, kuis dan info pengembang.

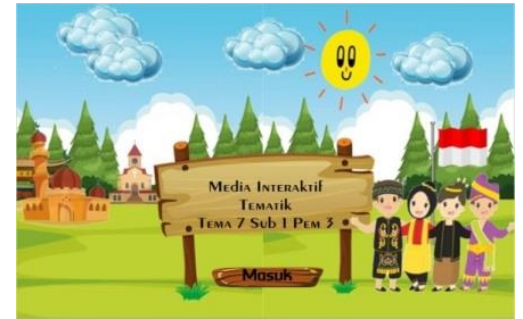

Gambar 2. Intro

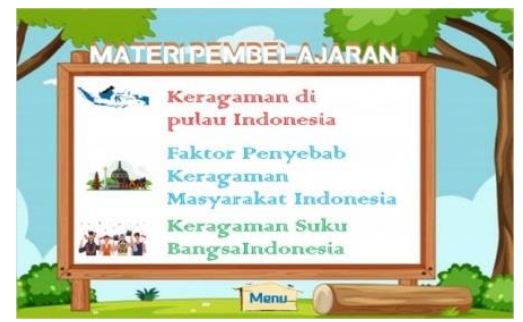

Gambar 4. Materi

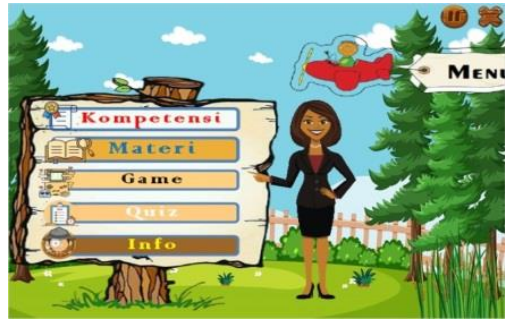

Gambar 3. Menu Utama

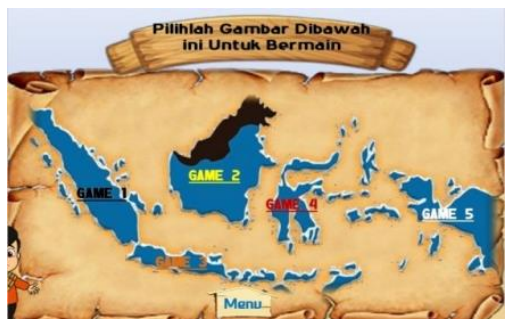

Gambar 4. Game

Development (Pengembangan), setelah media pembelajaran selesai di kembangkan dan siap diterapkan dalam pembelajaran, media terlebih dahulu dilakukan pengecekan dan validasi kepada ahli materi dan ahli media. Hasil pengujian dari ahli media dan materi ditunjukkan pada tabel 2 berikut.

Tabel 2. Uji Pakar

\begin{tabular}{lccccc}
\hline No. & Ahli/PAkar & Skor Ideal & Skor Aktual & AP\% & Kategori \\
\hline 1 & Ahli Materi Pembelajaran & 50 & 44 & $88 \%$ & Sangat Baik \\
2 & Ahli Media Pembelajaran & 85 & 67 & $78 \%$ & Baik \\
\hline
\end{tabular}

Berdasarkan tabel 2 dapat diketahui kelayakan media pembelajaran yang dikembangkan termasuk dalam kategori sangat baik dan baik sehingga dapat dikatakan media pembelajaran interaktif berbasis Artiqulate Storyline layak untuk digunakan sebagai media pembelajaran pada kelas IV SD.

Implementasi (Penerapan), uji terbatas ini dilakukan dengan pemberian media pembelajaran interaktif kepada siswa, kemudian siswa diminta untuk mengisi angket minat belajar yang sudah diberikan, angket berisi 20 pernyataan. Hasil analisis respon siswa ditunjukkan pada tabel 3 berikut.

Tabel 5. Validitas Agket Minat

\begin{tabular}{clcc}
\hline \multirow{2}{*}{ Rentang Indeks } & \multicolumn{2}{c}{ Kategori } & \multicolumn{2}{c}{ Ujicoba Produk Terbatas } \\
\cline { 3 - 4 } & Sangat tinggi & $\boldsymbol{f}$ & $\%$ \\
\hline $0,81-1,00$ & Tinggi & 10 & 15 \\
$0,61-0,80$ & Cukup & 5 & 50 \\
$0,41-0,60$ & Rendah & 1 & 15 \\
$0,21-0,40$ & Sangat rendah & 1 & 10 \\
$0,00-0,20$ & Jumlah & $\mathbf{2 0}$ & 10 \\
\hline & & & $\mathbf{1 0 0} \%$ \\
\hline
\end{tabular}


Berdasarkan table uji terbatas validitas dan reliabilitas mendapatkan hasil dari 20 butir pernyataan yang diuji cobakan ,3 (15\%) butir pernyataan termasuk kategori tingkat tinggi, $10(50 \%)$ butir pernyataan termasuk kategori tinggi, 5(15\%) butir pernyataan termasuk kategori cukup ,1(10\%) termasuk kategori rendah dan $1(10 \%)$ butir pernyataan termasuk kategori sangat rendah dengan rata-rata $r$ hitung tingkat validasi angket minat belajar siswa sebesar 0,598, maka pernyataan tersebut dinyatakan cukup valid. Sedangkan memperoleh hasil dari realibilitas cronbach's alpha sebesar 0,925 dan $\mathrm{N}$ of items sebanyak 20 yang termasuk kategori sangat reliabel.

Evalution (Evaluasi). Berdasarkan hasil uji ahli dan validitas media dapat dikatakan layak dan valid untuk digunakan meskipun masih ditemukan hasil uji ahli materi yang harus diperbaiki yaitu materi yang ada pada media karena materinya terlalu banyak dan gambar yang disajikan kecil dan kurang jelas sehingga media ini perlu dilakukan revisi kecil sebelum diuji cobakan di sekolah dasar.

\section{Pembahasan}

Berdasarkan hasil yang ditemukan maka disimpulkan bahwa media pembelajaran interaktif berbasis artiqulate storyline tematik terhadap minat belajar kelas IV SD dinyatakan valid dan layak digunakan hal ini disebabkan oleh beberapa faktor yaitu sebagai berikut. Pertama, media pembelajaran interaktif berbasis artiqulate storyline tematik terhadap minat belajar kelas IV SD layak digunakan karena dari hasil pengujian mendapatkan presentasi dari ahli media sebanyak $78 \%$ dan dari ahli materi mendapatkan $81 \%$ sehinga sudah memenuhi kriteria kelayakan. Hal ini tidak terlepas dari materi dan media dikembangkan. Media yang dikembangkan disesuaikan dengan kebutuhan anak SD khususnya siswa kelas IV. Kelayakan materi dapat ditinjau dari kesesuaian isi media dengan tujuan pembelajaran dan pada media ditinjau dari format media, kualitas media dan kesesuaian konsep media (Amirullah \& Hardinata, 2017; Wulandari et al., 2019; Yamin, 2020). Kedua, media pembelajaran layak digunakan karena mempermudah dan membantu guru dalam memnyampaikan materi pembelajaran dan mempermudah siswa memahami materi pembelajaran beserta dapat menarik perhatian dan minat siswa. dengan penggunaan media ini siswa dapat belajar interaktif secara mandiri. Media pembelajaran yang tepat dalam kegiatan pembelajaran akan menciptakan suasana efektif dan efisien sehingga memberikan dampak pada pemahaman siswa ( Mahadewi, 2012 ;Saputra, A., \& Filahanasari, 2020).

Ketiga, media interaktif yang dikembangkan dapat menumbuhkan minat belajar siswa karena dengan penyajian media ini siswa mengikuti pembelajaran sampai selesai, siswa merasa senang dan tertarik terhap medianya selain itu siswa juga mengerjakan perintah yang ada di media sampai selesai mulai dari petunjuk media, kompetensi, mempelajari materi, mengerjakan tugas, bermain game edukasi dan melakukan kuis. Media pembelajaran akan membuat pembelajaran lebih efektif dan efisien (Nurrita, 2018; Silalahi, 2020), medai pembelajaran membuat pembelajaran menarik sehingga membuat siswa aktif dan tertarik dalam mengikuti pembelajaran (Karo \& Rohani, 2018; Tafonao, 2018; Wahid et al., 2020) selian itu adalanya media pembelajaran juga dapat meningkatkan minat siswa dalam menikuti pembelajaran (Marwatoen, 2015). Tumbuhnya minat siswa dalam proses pembelajaran akan berpengaruh terhadap hasil bejar siswa. semakin tinggi minat siswa dalam proses pembelajaran maka hasil belajar siswa akan menunjukkan peningkatan. Oleh sebab itu pembuatan dan penggunaan media dalam proses pembelajaran harus disesuaikan dengan karateritik siswa dan perkembangan teknologi saat ini.

Beberapa penelitian yang mendukung hasil penelitian ini anatara lain (Yumini \& Rakhmawati, (2015) menyatakan bahwa penggunaan media pembelajaran interaktif berbasis Articulate Storylinen menghasilkan kelayakan media yang digunakan untuk menunjang kegiatan proses kegiatan pembelajaran di dalam kelas maupun saat pembelajaran mandiri. Rafmana \& Chotimah, (2018) menghasilkan multimedia interaktif 
berbasis articulate storyline dinyatakan valid, praktis dan mempunyai efek potensial untuk meningkatkan motivasi belajar siswa di SMA. Setyaningsih et al., (2020) menyatakan bahwa penggunaan media pembelajaran interaktif berbasis articulate storyline terhadap motivasi belajar dan hasil belajar IPS siswa kelas IV SD. Jadi, dapat dikatakan bahwa media-media interaktif dengan jenis aplikasi yang dikembangkan layak digunakan dan berdampak positif.

\section{Simpulan}

Media interaktif berbasis Artiqulate Storyline ini layak digunakan untuk dapat membantu guru kelas IV dalam menyampaikan materi pembelajaran dan membantu siswa untuk memahami materi dan menumbuhkan minat serta ketertarikan siswa untuk mengikuti kegiatan pembelajaran. Saran untuk peneliti selanjutnya pengembangan media alangkah baiknya dipersiapkan secara matang, masukan konten-konten yang lengkap dan menarik, selain itu dapat menggunakan desain gambar sendiri agar tidak terdeteksi plagiat saat media akan di unggah di playstore, pengunggan media di playstroe akan membatu memudahkan siswa dalam mendownload media pembelajaran.

\section{Daftar Pustaka}

Agustini, P. P., Kristiantari, M. . R., \& Putra, D. K. N. S. (2016). Penerapan Model Pembelajaran Berbasis Masalah Berbantuan Media Audio Visual Untuk Meningkatkan Hasil Belajar Keterampilan Menyimak Tema Sejarah Peradaban Indonesia Pada Siswa Kelas V Sdn 8 Sumerta. MIMBAR PGSD Undiksha, 4(1). https://doi.org/10.23887/jjpgsd.v4i1.7265

Amirullah, G., \& Hardinata, R. (2017). Pengembangan Mobile Learning Bagi Pembelajaran. JKKP (Jurnal Kesejahteraan Keluarga Dan Pendidikan), 4(02), 97101. https://doi.org/https://doi.org/10.21009/JKKP.042.07

Andriani, S. (2016). Pengaruh motivasi belajar dan penggunaan media pembelajaran terhadap hasil belajar IPS siswa kelas IV di SDN Mayangan 6 kota probolinggo. Jurnal Penelitian Dan Pendidikan IPS, 10(1), 101-118. http://ejournal.unikama.ac.id/index.php/JPPI/article/view/1710

Angela, T. (2014). Challenges to Meaningful Learning in Social Studies - The Key Competences as an Opportunity to Students' Active Participation. Procedia Social and Behavioral Sciences, 128, 192-197. https://doi.org/10.1016/j.sbspro.2014.03.142

Arda, Saehana, S., \& Darsikin. (2015). Pengembangan Media Pembelajaran Interaktif Berbasis Komputer Untuk Siswa Smp Kelas Viii. E-Jurnal Mitra Sains, 3(1), 69-77. https://media.neliti.com/media/publications/153834-ID-pengembangan-mediapembelajaran-interakt.pdf

Gurung, R. A. R. (2020). Call It Out: Recognizing Good Teaching and Learning. Journal of Applied Research in Memory and Cognition, 9(2), 161-164. https://doi.org/10.1016/j.jarmac.2020.02.003

Henriksen, D., Richardson, C., \& Shack, K. (2020). Mindfulness and creativity: Implications for thinking and learning. Thinking Skills and Creativity, 37(December 2019), 100689. https://doi.org/10.1016/j.tsc.2020.100689

Idris, I., \& Sida, S. C. (2019). Pengaruh Model Problem Based Learning Terhadap Keterampilan Proses dan Hasil Belajar IPS Siswa SD. Indonesian Journal Of Primary Education, 3(2), 58-63.

Idris, Irfandi, Sida, S. C., \& Idawati, I. (2019). Pengaruh Model Problem Based Learning Terhadap Keterampilan Proses dan Hasil Belajar IPS Siswa SD. Indonesian Journal Of Primary Education, 3(2), 58-63. https://ejournal.upi.edu/index.php/IJPE/article/view/21849 
Jundu, R., Jehadus, E., Nendi, F., Kurniawan, Y., \& Men, F. E. (2019). Optimalisasi Media Pembelajaran Interaktif dalam Meningkatkan Kemampuan Matematis Anak di Desa Popo Kabupaten Manggarai. E-Dimas: Jurnal Pengabdian Kepada Masyarakat, 10(2), 221. https://doi.org/10.26877/e-dimas.v10i2.3353

Karo, I. R., \& Rohani. (2018). Manfaat Media Dalam Pembelajaran. Jurnal Pendidikan Dan Matematika, 7(1), 91-96. http://jurnal.uinsu.ac.id/index.php/axiom/article

Kostiainen, E., Ukskoski, T., Ruohotie-Lyhty, M., Kauppinen, M., Kainulainen, J., \& Mäkinen, T. (2018). Meaningful learning in teacher education. Teaching and Teacher Education, 71, 66-77. https://doi.org/10.1016/j.tate.2017.12.009

Kumalasari, M. P. (2018). Kepraktisan Penggunaan Multimedia Interaktif pada Pembelajaran Tematik Kelas IV SD Maharani Putri Kumalasani PGSD Universitas Muhammadiyah Malang Perkembangan ilmu pengetahuan dan teknologi ( IPTEK ) bergerak secara dinamis seiring dengan perkembangan zam. Jurnal Bidang Pendidikan Dasar (JBPD), 2(1), 1-11. http://ejournal.unikama.ac.id/index.php/JBPD/article/view/2345/1726

Marwatoen, F. (2015). Pengaruh Media Presentasi dan Komik dalam Pembelajaran Biologi terhadap Hasil Belajar ditinjau dari Motivasi Siswa. Prisma Sains: Jurnal Pengkajian IImu Dan Pembelajaran Matematika Dan IPA IKIP Mataram, 3(2), 71. https://doi.org/10.33394/j-ps.v3i2.976

Nurrita, T. (2018). Pengembangan media pembelajaran untuk meningkatkan hasil belajar siswa. MISYKAT. Jurnal IImu-IImu Al-Quran, Hadist, Syari'ah Dan Tarbiyah, 3(1), 171.

Rafmana, H., \& Chotimah, U. (2018). Pengembangan Multimedia Interaktif Berbasis Articulate Storyline Untuk Meningkatkan Motivasi Belajar Siswa Pada Mata Pelajaran PKn Kelas XI Di SMA Srijaya Negara Palembang. Jurnal Bhinneka Tunggal Ika, 05(1), 52-65. https://ejournal.unsri.ac.id/indeks.php/jbti/ article/download/7898/pdf

Rezeki, S., \& Ishafit, I. (2017). Pengembangan Media Pembelajaran Interaktif untuk Sekolah Menengah Atas Kelas XI pada Pokok Bahasan Momentum. Jurnal Penelitian \& Pengembangan Pendidikan Fisika, 3(1), 29. https://doi.org/10.21009/1.03104

Safriandono, A. N., \& Charis, M. (2014). Rancang Bangun E-Lembar Kerja Siswa sebagai Media Pembelajaran yang Praktis, Fleksibel dan Edukatif Berbasis Web. Jurnal Teknik-UNISFAT, 10(1), 25-35.

Saputra, A., \& Filahanasari, E. (2020). Pengembangan Media Video untuk Pengenalan Karir di Taman Kanak-Kanak. Jurnal Pedagogi Dan Pembelajaran. Jurnal Pedagogi Dan Pembelajaran, Vol. 3, No, 499-507. https://doi.org/doi: http://dx.doi.org/10.23887/jp2.v3i3.29110

Saputro, E. B., Sopyan, A., \& Subali, B. (2016). Kontribusi Media Pembelajaran Interaktif Untuk Membantu Meningkatkan Pemahaman Konsep Pembiasan Cahaya Pada Siswa Kelas X Sma. Phenomenon: Jurnal Pendidikan MIPA, 3(2), 103-110. https://doi.org/10.21580/phen.2013.3.2.140

Setyaningsih, S., Rusijono, R., \& Wahyudi, A. (2020). Pengaruh Penggunaan Media Pembelajaran Interaktif Berbasis Articulate Storyline Terhadap Motivasi Belajar dan Hasil Belajar Siswa Pada Materi Kerajaan Hindu Budha di Indonesia. Didaktis: Jurnal Pendidikan Dan IImu Pengetahuan, 20(2), 144-156. https://doi.org/10.30651/didaktis.v20i2.4772

Shalikhah, N. D., Primadewi, A., \& Iman, M. S. (2018). Media Pembelajaran Interaktif Berbantu Software Lectora inspire. Desimal: Jurnal Matematika, 1(2), 237. 
https://doi.org/10.24042/djm.v1i2.2583

Silalahi, M. V. (2020). Development of E-Modules Based on Exe-Learning on Topics of Reaction Rate Against Student Learning Outcomes Mechanical Engineering. 3(2), 114-120. https://doi.org/: https://doi.org/https://doi.org/10.31764/ijeca.v3i2.2672

Sofnidar, S., \& Yuliana, R. (2018). Pengembangan Media Melalui Aplikasi Adobe Flash Dan Photoshop Berbasis Pendekatan Saintifik. Jurnal Gentala Pendidikan Dasar, 3(2), 257-275. https://doi.org/10.22437/gentala.v3i2.6761

Tafonao, T. (2018). Peranan Media Pembelajaran Dalam Meningkatkan Minat Belajar $\begin{array}{llll}\text { Mahasiswa. Jurnal Komunikasi Pendidikan, } & 103 .\end{array}$ https://doi.org/10.32585/jkp.v2i2.113

Tegeh, I. M., Simamora, A. H., \& Dwipayana, K. (2019). Pengembangan Media Video Pembelajaran Dengan Model Pengembangan 4D Pada Mata Pelajaran Agama Hindu. Julnar Mimbar IImu.

Usfiyana, I. (2019). Pengembangan Media Pembelajaran Berbasis Adobe Flash Cs6 Untuk Mata Pelajaran Teknologi Informasi Dan Komunikasi ( Tik ) Di Smp AlIshlah Semarang. Joined Journal, 2(1), 60-70. http://ejournal.ivet.ac.id/index.php/jiptika/article/view/865

Wahid, A., Handayanto, A., \& Purwosetiyono, F. X. D. (2020). Pengembangan Media Pembelajaran Berbasis Etnomatematika Menara Kudus Menggunakan Adobe Flash Professional CS 6 pada Siswa Kelas VIII. Jurnal Matematika Dan Pendidikan $\quad$ Matematika, 2(1), 58-70. http://journal.upgris.ac.id/index.php/imajiner/article/download/5765/3075

Widjayanti, W. R., Masfingatin, T., \& Setyansah, R. K. (2018). Media Pembelajaran Interaktif Berbasis Animasi pada Materi Statistika untuk Siswa Kelas 7 SMP. Jurnal Pendidikan Matematika, 13(1), 101-112. https://doi.org/10.22342/jpm.13.1.6294.101-112

Wulandari, D. A., Murnomo, A., Wibawanto, H., \& Suryanto, A. (2019). Pengembangan Mobile Learning berbasis Android pada Mata Pelajaran Rekayasa Perangkat Lunak di SMK Sultan Trenggono Kota Semarang. Jurnal Teknologi Informasi Dan IImu Komputer, 6(5), 577-584. https://doi.org/DOI: http://dx.doi.org/10.25126/jtiik.201965994

Yamin, A. (2020). Pengembangan Media Pembelajaran Berbasis Aplikasi Android Materi Integrasi Nasional dalam Bingkai Bhinneka Tunggal Ika bagi Siswa Kelas X SMAN 1 Puri Mojokerto. Kajian Moral Dan Kewarganegaraan, 8(2).

Yumini, S., \& Rakhmawati, L. (2015). Pengembangan Media Pembelajaran Interaktif Berbasis Articulate Storyline Pada Mata Diklat Teknik Elektronika Dasar Di Smk Negeri 1 Jetis Mojokerto. Jurnal Pendidikan Teknik Elektro, 4(3), 845-849. https://jurnalmahasiswa.unesa.ac.id/index.php/jurnal-pendidikan-teknik-

elektro/article/view/12673 